\title{
WILLIAM OF ST. AMOUR'S \\ DE PERICULIS NOVISSIMORUM TEMPORUM: A False Start to Medieval ANTIFRATERNALISM?*
}

\author{
G. Geltner
}

In the gallery of medieval antifraternal authors, no figure features more prominently than that of William of St. Amour, the "Hammer of the Friars." Master of theology at Paris in the $1250 \mathrm{~s}$, at the height of the mendicants' so-called golden age, William led an audacious assault on the friars which would resonate down the centuries, despite the utter failure of his own campaign. Indeed, it is probably as a literary fountainhead rather than an able ecclesiologist that William earned his fame. ${ }^{2}$ It is in this sense that the relations between his magnum opus, De periculis novissimorum temporum (On the Dangers of the Last Times, written in 1256), and his putative followers require fuller elucidation. For the appropriation of Williamine arguments and topoi was in no way as straightforward as is often thought. It was John Fleming who pioneered this observation in his 1966 article, "The Antifraternalism of the Summoner's Tale." And although

* This essay develops several observations made in my broader study, William of Saint Amour's De Periculis Novissimorum Temporum: A Critical Edition, Translation, and Introduction, Dallas Medieval Texts and Translations 8 (Leuven: Peeters, 2008) [henceforth DP], which is the source of all quotations from the treatise.

${ }^{1}$ C.H. Lawrence, Medieval Monasticism: Forms of Religious Life in Western Europe in the Middle Ages, 3rd ed. (Harlow, England: Longman, 2001), 234; Gérard Sivery, Saint Louis et son siècle (Paris: Tallendier, 1983), 487-91.

2 John V. Fleming, "The Friars and Medieval English Literature," in The Cambridge History of Medieval English Literature, ed. David Wallace (Cambridge: Cambridge University Press, 1999), 354.

3 Journal of English and Germanic Philology 65 (1966): 688-700. 
scholars continue to debate the nature of medieval antifraternalism (as this very volume demonstrates; see especially the contributions by Lawrence Clopper and Penn Szittya), it has become increasingly difficult to draw a straight line between the acidic polemics of the mid-thirteenth century and later confrontations, whether literary, doctrinal, or physical, between mendicants and their various antagonists.

The present essay contributes to this debate by arguing that what sets William apart from the vast majority of the friars' preReformation critics, including the most avid among them, are the objectives of his disparagement rather than his rhetoric. For William denied the orthodoxy of religious mendicancy tout court ${ }^{4}$ - a position that was rare prior to the religious revolutions of the early sixteenth century. By contrast, most contemporary and later critics, whether professional theologians, satirists, or less learned members of medieval society, sought to curb or simply protest the friars' access to worldly power and privileges, not abolish the orders themselves. These fundamentally different attitudes, however, are often ignored or undeservedly ironed out in modern discussions of medieval antifraternalism. ${ }^{5}$ Thus, examining the relations between William's ecclesiology and the positions advanced by later critics affords a more nuanced understanding of prevailing attitudes toward medieval friars.

\section{De periculis novissimorum temporum: Religious Mendicancy Delegitimized}

The immediate context for the publication of De periculis is easily traced to the heated debates between mendicant

4 William never criticized Franciscan life per se, nor did he distinguish among the mendicant orders, despite their different comportments in the context of the University Quarrels.

${ }^{5}$ Notably, Penn R. Szittya, The Antifraternal Tradition in Medieval Literature (Princeton: Princeton University Press, 1986), esp. ch. 2; and Michael Robson, The Franciscans in the Middle Ages (London: The Boydell Press, 2007), 4 and ch. 13. 
theologians and their allies, on one hand, and the Parisian secular masters and their supporters, on the other, in the midthirteenth century. The events, generally known as the University Quarrels, were sparked by the second cessation of teaching at the university in 1253 , following the brutalization of several students by the local night watch. The university suspended its activities to protest what it claimed was gratuitous violence. Yet the measure failed to win the immediate cooperation of the popular mendicant studia. The friars' cool response was construed by some secular masters as a repeated display of their lack of collegiality in the aftermath of the university's Great Dispersion in 1229 , during which the friars gained a lucrative chair in theology. And the sentiment was only exacerbated by the Dominicans' demand to secure their now threatened possession of a second theology chair if they were to participate in the strike. In the ensuing conflagration the secular masters, headed by William of St. Amour, appealed to the papal curia and its delegates to eject the mendicant masters from the corporate university body.

The antimendicant party was quick to point out that the friars had no place at the university to begin with. This was a particularly delicate point in the case of the Franciscans, whose founder, a self-professed simplex et idiota, strongly opposed the Minorites' pursuit of formal learning. Even the Dominican Order, which was ideologically committed to the study of theology and canon law, conceived of advanced studies merely as an act of "bending a bow," a preparatory stage to their preaching missions. ${ }^{6}$ Yet by the middle of the thirteenth century, mendicant masters and students were playing an ever-greater role in urban higher education, including the occupation of chairs at the faculty of theology, the crown jewel of the University of Paris.

The apparent discrepancy between the friars' theory and practice in the realm of letters, as well as the contrast between their professed humility and opportunism in the context of the strike, marked them in their opponents' eyes as hypocrites. The accusation was strong enough, yet William personally did not

${ }^{6}$ M. Michèle Mulchahey, "First the Bow is Bent in Study ...": Dominican Education before 1350 (Toronto: Pontifical Institute of Mediaeval Studies, 1998). 
stop there. As the parties continued to litigate in various venues, he took to the pulpit and the quill, claiming that the friars were false Apostles who abused their confessing privileges, and then moved to brand all religious mendicants as nothing less than heretical harbingers of the Antichrist:

Thus it appears from the above who are penetrators of homes and who are the false; it even appears that through such men the dangers of the last times will threaten or already are threatening the entire church. ${ }^{7}$

The apparently outrageous allegations, however, were linked in a curious way to a recent scandal in the Franciscan Order.

Among the "incriminating" evidence at William's disposal was a compilation known as the Introductorius in evangelium eternum (Introduction to the Eternal Gospel). The work, published in 1254 by the Franciscan Gerard of Borgo San Donnino, then residing in Paris, intended to advance one side in an internal debate regarding the correct way of interpreting the Minorites' rule. Although the Introductorius was factional, unauthorized, and generally tangential to the tensions between secular and mendicant professors, it contained several inflammatory observations, which William readily exploited. As its title suggests, the treatise drew on the writings of Abbot Joachim of Fiore, a venerated exegete, visionary, and monastic reformer who died in 1202, that is, before the foundation of any mendicant order. Joachim propounded a revolutionary theology of history in which three ages unfold: that of the Father, the Son, and the Holy Spirit. In this scheme, the latter age, or status, would be the culmination of the Godhead's work on earth, ushering in a new and complete "spiritual" understanding of divine truth: an eternal gospel. Importantly, he also claimed that this approaching era would be exemplified by the lives of "new men" (novi viri). Despite Joachim's own elusiveness and ambiguity, his Franciscan followers in particular insisted on a literal interpretation of the terms "eternal gospel" and "new men," identifying the abbot's

\footnotetext{
${ }^{7} \mathrm{DP}, 59$.
} 
works as the former and their own order as the latter. The Franciscan compilers of the Introductorius also established 1260 as the year in which the new age would commence, that is, six years thence.

The publication of the Introductorius could not have come at a worse time for the Parisian mendicants. And although the work was condemned, ordered to be burned, and its authors severely punished, the antimendicant party employed it to demonstrate that all friars were apocalyptic forerunners of the Antichrist. As William put it in the eighth chapter of De periculis, which enumerates several signs of the Antichrist's approach,

The second sign is that, already in the year of the Lord twelve hundred and fifty-four, that teaching which will be preached in the time of the Antichrist, namely, the aforesaid Eternal Gospel, was publicly submitted for examination in Paris.... Whence it is certain that it would already be preached unless something prevented it....

The seventh sign is that, with the approaching consummation of the era, certain men, who in the church seem most zealous for the faith and appear to love Christ greatly, will cast off the gospel of Christ and adhere to the Eternal Gospel, which entirely overwhelms Christ's faith. Whence the love of many, by which the word of God is guarded, will entirely abate. ${ }^{8}$

The special eschatological role allocated to the friars by the Introductorius, as well as what could be construed as a gross devaluation of the Bible, played into the antimendicant party's hands. In a sense, De periculis is a complete reversal of (and some would say a parody on) the arguments advanced by the Introductorius. How, William would repeatedly ask, could such hypocrites blatantly subvert the order of the church and not be recognized as false apostles and the harbingers of the Antichrist?

${ }^{8}$ DP, 77-79 and 83. 
He who cannot see that these signs are already present in the church is evidently asleep. Whence let him follow the Apostle's counsel, I Thes 5[:6], let us not sleep, but be vigilant. Be vigilant, therefore, just men, I Cor 15[:34], and through the aforesaid signs, which already appear, you will see that the end of the era is near, and that the sorrow, which will come to pass in the time of the Antichrist, already begins. ${ }^{9}$

That the friars were degenerate, however, was merely symptomatic. To William's mind, the orders' very existence posed the more serious threat to the ordained hierarchy of the church, not due to their comportment, but because they occupied a place outside the two, divinely ordained components of the ecclesiastical hierarchy, namely the clergy (prefigured by the apostolic community) and monks (prefigured by the early disciples). The influential scheme was originally developed by Dionysius the Pseudo-Areopagite in his Ecclesiastical Hierarchy and Celestial Hierarchy (early sixth century), and constituted formal doctrine by the twelfth century. In the words of Gratian, cited in De periculis:

For, since we recognized that there are no more than two orders among the disciples, that is, twelve apostles and seventy-two disciples, whence this third order emerged we do not know. And what lacks a reason must be extirpated. ${ }^{10}$

There is little doubt that the new mendicant orders fit awkwardly into this scheme. Yet their success and popularity undermined the importance of the accepted division of labor in the church. It was this threat to the roles of the secular clergy and the institution of monasticism that William found particularly disturbing. In this sense, weaving the friars' advent

${ }^{9} \mathrm{DP}, 83$.

${ }_{10}$ DP, 53; citing Gratian, Concordia discordantium canonum, pt. I, dist. 68, c. v $\S 1$, in Corpus iuris canonici, 2 vols., ed. Emil Friedberg (Leipzig: B. Tauchnitz, 1879-1881), 1: 255. 
and modus operandi into an apocalyptic narrative was merely an effective rhetorical tool, a means to an end. Theoretically, it would have mattered little if the friars amended their ways; it was their unjustified existence that threatened the ordained church hierarchy, however anachronistically it was construed by William.

Ironically, by appropriating a binary apocalyptic narrative, which distinguished neatly between the sons of light and darkness (as did the Introductorius), William precipitated his own downfall. The friars' many powerful allies, including Pope Alexander IV (a former Cardinal Protector of the Franciscan Order) and King Louis IX of France (St. Louis), found their own association with the Antichrist too outlandish to bear. Soon after the publication of De periculis in March or April of 1256, and following a series of public sermons to the same effect, the Capetian ruler identified William as an obstacle to reconciliation between the disputing parties and dispatched the treatise to be examined at the papal court. Six months later the work was condemned by a designated commission, which ordered - but never thoroughly implemented - the destruction of all its copies. William was exiled to his native St. Amour in Burgundy, technically outside Capetian jurisdiction, and his collaborators were forced to recant or resign. These actions effectively dissolved the antimendicant party and concluded the first - and, in a sense, only - chapter in the history of medieval antifraternalism.

\section{Critiques of Friars after William of St. Amour}

William found no legitimate place for the new mendicant orders in the hierarchy of the church. His ecclesiology, as developed in De periculis and elsewhere, aimed at the orders' abolition, not rehabilitation. Thus, exposing the friars' hypocrisy and moral laxity was a means to a radically different end than reform. But did William's nominal followers throughout the thirteenth and fourteenth centuries share the same perspective? 
The remainder of this essay is an examination of three forms of criticisms of medieval friars, as expressed in contemporary belles lettres, theology and more palpable social actions.

\subsection{Literary Critiques}

De periculis may have been William's swan song, but it had an enthusiastic following. The treatise repeatedly echoes in thirteenth-century and later literature, from the poetry of Rutebeuf and Jean de Meun, to the tales of Boccaccio and Franco Sachetti, to the writings of Chaucer, Langland, Gower, and others. ${ }^{11}$ Williamine topoi circulated in Europe throughout the Renaissance, for instance, with Rabelais and in Machiavelli's Clizia, and well into the early modern period, from Thomassin, Bossuet, and Olier, to Marlowe's Doctor Faustus. And more or less informed allegations of the friars' corruption and worldliness continue to flourish in our times, from Blackadder's Friar Bellows to the "roasting" of prominent comedians at the New York Friars Club.

The frequent recourse to William's works by authors who openly criticized the mendicant orders accounts for his reputation as the wellspring of antifraternal literature. Yet there appears to be a wide range of approaches to his legacy. To take one famous example, the Parisian poet Rutebeuf, William's contemporary and partisan, was originally an avid supporter of mendicant religiosity. ${ }^{12}$ Later, however, he strove to defend his exiled friend and the secular masters' cause by inveighing against what he believed was a corrupted movement. But Rutebeuf scarcely maintained William's categorical objection to organized

${ }^{11}$ For a full bibliography see DP, 32-33; and Patricia Anne Odber de Baubeta, Anticlerical Satire in Medieval Portuguese Literature (Lewiston: The Edwin Mellen Press, 1992).

12 Rutebeuf, "Le dit des Cordeliers," in Euvres complètes de Rutebeuf, 2 vols., ed. Edmond Faral and Julia Bastin (Paris: Picard, 1959-60), 1: 231-7. 
mendicancy, for his tirades focused on the secular masters' enemies rather than on the friars generally. ${ }^{13}$

Other writers developed several of William's themes in ways that abandoned the original context of De periculis as well as its main thrust. Notable among these are Jean de Meun, Giovanni Boccaccio, and Geoffrey Chaucer. The friar-characters featuring in the Roman de la Rose (Faus Semblant), the Decameron (Fra Cipolla and "Fra" Tedaldo), and the Summoner's Tale (Friar John) are engaged in a much broader social critique than that present in William's works. They are, moreover, experiments in the fabrication of Cretan-liar characters, which their authors employed to comment, among other themes, on the meaning of art and poetry and their complex relation to reality. ${ }^{14}$ In any case, scholars have long abandoned the quest for the "real" men behind these characters. Indeed, Jean Batany and Jill Mann underscored the enormous debt of antifraternal literature to the long-standing conventions of estate satire - the former arguing that friars are often indistinguishable from monks or clergymen in generic protests against corruption $;{ }^{15}$ the latter asserting that "[f]ar from drawing new inspiration from real life, Chaucer seems to have been most stimulated by the possibility of exploiting a rich literary tradition" in his treatment of monks and friars. ${ }^{16}$ More

13 See Edward Billings Ham, Rutebeuf and Louis IX, University of North Carolina Studies in the Romance Languages and Literatures 42 (Chapel Hill, NC: The University of North Carolina Press, 1962).

${ }^{14}$ See G. Geltner, "Faux Semblants. Antifraternalism Reconsidered in Jean de Meun and Chaucer," Studies in Philology 101 (2004): 357-80; Nicholas Havely, "Chaucer, Boccaccio, and the Friars," in Chaucer and the Italian Trecento, ed. P. Boitani (Cambridge: Cambridge University Press, 1983), 249-68.

15 "L'image des franciscains dans les 'Revues d'États' du XIIIe au XVIe siècle," in Mouvements franciscains et société française XIIe-XXe siècles, ed. André Vauchez (Paris: Beauchesne, 1984), 61-74.

16 Jill Mann, Chaucer and Medieval Estates Satire (Cambridge: Cambridge University Press, 1973), 17; adding (39), "As with the Monk, Chaucer seems to have more ends in view than moral criticism of the character he is describing." The view is corroborated by Odber de Baubeta, Anticlerical Satire, esp. 1-58. And see Arnold Williams, "Chaucer and the Friars," Speculum 28 (1953): 499-513; Fleming, "The Antifraternalism of the Summoner's Tale"; Havely, "Chaucer, Boccaccio, 
recently, Lawrence Clopper turned a dominant interpretation of Piers Plowman virtually on its head by demonstrating that Langland's sincere concerns about religious mendicancy, especially regarding the Franciscan Order, reflect the friars' departure from their founder's ideals rather than a wish to see them eradicated. ${ }^{17}$

If so, what Penn Szittya and others have dubbed "the medieval antifraternal tradition" shares much common ground with numerous home-grown critics, from Joachimite Franciscans and their Spiritual successors, to undisputedly orthodox disciplinarians such as Bonaventure and Humbert of Romans all of whom decried the friars' fallenness in unambiguous terms and for the stated purpose of their improvement, not elimination.

The idealist-reformist approach to religious mendicancy evident in some medieval satire discloses the real chasm between William of St. Amour and many of his literary successors: given William's absolute denial of the mendicants' orthodoxy, including what must have been a jarring dismissal of St. Francis's and St. Dominic's lives as exemplary, it is clear that he made no distinction between mendicants and mendicancy. Accordingly, he never envisaged the history of the mendicant orders as one of continuous decline from an original golden age, as did later critics, including many members of the orders themselves.

\subsection{Theological Critiques}

While writers of fiction employed friar-characters in the service of moral satire, theologians tended to engage more discrete doctrinal issues. ${ }^{18}$ Major scholastic thinkers, from Gerard

and the Friars"; idem, "Chaucer's Friar and Merchant," Chaucer Review 13 (1978-89): 337-45.

17 Lawrence M. Clopper, "Songes of Rechelesnesse": Langland and the Franciscans (Ann Arbor, MI: University of Michigan Press, 1997). Clopper summarizes his main argument in "Langland's Persona: An Anatomy of the Mendicant Orders," in Written Work: Langland, Labor, and Authorship, eds. Steven Justice and Kathryn Kerby-Fulton (Philadelphia: University of Pennsylvania Press, 1997), 144-84.

18 Beyond the bibliography in DP, 33-34, see Andrea Tabarroni, Paupertas Christi et apostolorum: l'ideale francescano in discussione 
of Abbeville and Nicolas of Lisieux, William's partisans at Paris, to Henry of Ghent, John of Pouilly, and Jean d'Anneux, to Richard FitzRalph and John Wyclif, underscored the friars' fallen state, challenged mendicant privileges, and called for the orders' reform - sometimes by frequent and explicit reference to William's works. But to what extent was such recourse either uniform or in keeping with William's own reactionary ecclesiology?

For the first few decades following William's banishment, his original collaborators avoided using arguments that challenged the legitimacy of organized religious mendicancy. Instead, they chose to focus their energies on defining evangelical perfection and on limiting or eliminating individual privileges given to the mendicants, such as confession, preaching, and burial rights. ${ }^{19}$ Decades later, even a staunch supporter of John XXII such as Jean d'Anneux, in his Filios enutrivi (1328), aimed at curbing the Franciscans' privileges, not abolishing the order, however much it was founded on certain errors. ${ }^{20}$ On the other hand, English critics such as FitzRalph and Wyclif (despite the latter's initial sympathy) had no qualms about reviving William's radical ecclesiology, the former underscoring the incongruence of mendicant orders with church hierarchy, the latter denying the very legitimacy of such a hierarchy in the first place. Both

(1322-1324) (Rome: Istituto storico italiano per il Medio Evo, 1990). The textual point of departure for most pro-mendicant writers after Bonaventure and Aquinas was Manus que contra Omnipotentem tenditur, probably written by the Franciscan Thomas of York. See Max Bierbaum, Bettelorden und Weltgeistlichkeit an der Universität Paris. Texte und Untersuchungen zum literarischen Armuts- und Exemtionsstreit des 13. Jahrhunderts (1255-1272), Franziskanische Studien 2. Beiheft (Münster: Aschendorff, 1920), 36-168; and F. Pelster, "Der Traktat 'Manus que contra Omnipotentem tenditur' und sein Verfasser," Archivum Franciscanum Historicum 15 (1923): 3-22.

19 See Sophronius Clasen, Der hl. Bonaventura und das Mendikantentum. Ein Beitrag zur Ideengeschichte des Pariser Mendikantenstreites (1252-1272), Franziskanische Forschungen 7 (Werl/Westfalen: Verlag Franziskus-Druckerei, 1940), 1-12.

20 The treatise is edited in Susanne Starcke-Neumann, Johannes von Anneux. Ein Fürstenmahner und Mendikantengegner in der ersten Hälfte des 14. Jahrhunderts (Mammendorf: Septem Artes, 1996), 213-53. 
demanded the orders' abolition, be it de facto or de jure FitzRalph through calling for their total submission to the ordained ecclesiastical hierarchy, Wyclif by demanding their eradication along with the visible church. Thus it seems that, from a century's distance and in different circumstances, William's English followers in particular perpetuated anew his fundamental doctrines, a tendency also evident in James le Palmer's Omne bonum, a late fourteenth-century compilation replete with antifraternal lore. ${ }^{21}$ Nonetheless, these examples appear from a broader perspective to be important but extreme responses. And what accounts for their centrality in the modern study of the phenomenon has more to do with later developments, not prevalent medieval attitudes.

The antifraternal polemics of FitzRalph, Wyclif, and the latter's followers were often inscribed into a teleological narrative of English anticlericalism that prepared the way for the English Reformation. ${ }^{22}$ A comparable search for origins in pre-Hussite central Europe and among pre-Lutheran German theologians led early Protestant scholars to tie Williamine antipapal and antifraternal arguments with the religious revolutions of the early sixteenth century. In fact, we owe the first printed edition of two of William's sermons (1555) and the publication of his collected works (1632) to just such efforts. ${ }^{23}$ On the other hand, more rigorous approaches to the regional dissemination of William's works (and those of his late-medieval followers) remain

21 Lucy Freeman Sandler, Omne Bonum: A Fourteenth-Century Encyclopedia of Universal Knowledge, 2 vols. (London: Harvey Miller Publishers, 1996), 1: 46-47; Szittya, The Antifraternal Tradition, 67-81 and Appendices A and B. Wendy Scase, Piers Plowman and the New Anticlericalism (Cambridge: Cambridge University Press, 1989), lays a particular emphasis on contextual discontinuities between the antifraternal literatures of the thirteenth and late-fourteenth centuries.

${ }^{22}$ See Katherine Walsh, A Fourteenth-Century Scholar and Primate: Richard FitzRalph in Oxford, Avignon and Armagh (Oxford: Clarendon Press, 1981), 349-451.

${ }^{23}$ Antilogia papae, hoc est, De corrupto ecclesiae statu \& totius cleri papistici peruersitate... (Basel: I. Oporini, 1555), 5-137; Guillielmi de S. Amore Opera omnia quae reperiri potuerunt ... (Coûtances: Alitophilos, 1632; reprinted Hildesheim and New York: G. Olms, 1997). 
a desideratum. With the exception of Vlastimil Kybal's work on Matthew of Janov and Geoffrey Dipple's study of Johann Eberlin von Günzburg, and despite the abundance of manuscript evidence, there exists no full study of the transmission of William's works across central Europe. ${ }^{24}$ There is likewise no examination of the extent to which William may have influenced "proto-reformers" such as Konrad of Megenberg, Konrad of Waldhäusen, and Jan Milíč of Kroměříž. ${ }^{25}$ And a similar lacuna (perhaps reflecting the subject's irrelevance) exists concerning the Near East and Scandinavia. In any case, there is little evidence for a continuous tradition linking William of St. Amour's reactionary ecclesiology to the prominent role supposedly played by antifraternalism and anticlericalism in the making of the Protestant Reformation.

In the final account, the extent to which William of St. Amour inspired medieval antifraternal belletristics and theology fundamentally depends on how strictly we define this literature in keeping with William's own ideas about the pursuit of religious mendicancy. Such an evaluation, in turn, is contingent upon a better understanding of William's professed or alleged followers, whether poets, storytellers, polemicists, or professional theologians. On a wider scale still, particular works of medieval fiction that are generally reputed as antifraternal deserve more detailed studies that may increase our understanding of their broader cultural reception. ${ }^{26}$ While most of this research is still to

${ }^{24}$ See Matthiae de Janov Regulae Veteris et Novi Testamenti, ed. Vlastimil Kybal, 6 vols. (Innsbruck: Wagner University, 1908-11), 3: 252314; Geoffrey L. Dipple, Antifraternalism and Anticlericalism in the German Reformation: Johann Eberlin von Günzburg and the Campaign against the Friars (Brookfield, VT: Scolar Press, 1996).

25 See Christopher Ocker, "Contempt for Friars and Contempt for Jews in Late-Medieval Germany," in Friars and Jews in the Middle Ages and the Renaissance, ed. Steven J. McMichael and Susan E. Myers (Leiden: Brill, 2004), 145-46.

26 As has been done, for instance, by Scase, Piers Plowman and the New Anticlericalism; Sylvia Huot, The Romance of the Rose and Its Medieval Readers: Interpretation, Reception, Manuscript Transmission (Cambridge: Cambridge University Press, 1993); Geltner, "Faux Semblants," 365-69, 377-78. 
be done, there is little evidence of a body of antifraternal literature committed to the stated ecclesiological goals of $D e$ periculis, namely abolishing the mendicant orders.

\subsection{Violence against Friars}

There is yet another, little-studied aspect of medieval attitudes toward mendicants, namely instances of physical aggression against them. Although there is no shortage of documented assaults on friars by Catholics (as distinguished from heretics, Muslims, and Jews), there has been no attempt to treat such events systematically. The final section fills no such lacuna, but rather offers a cursory view of such phenomena, and then proceeds to examine whether they share any common ground, and to what extent they exemplify or stem from Williamine ecclesiology.

Violence against friars can be interpreted as a palpable expression of popular or individual resentment of the brethren's activities or general standing. Yet the extant records rarely clarify the express goals and backgrounds of such attacks. One available point of departure is the friars' involvement in persecuting heretics in regions such as Lombardy and Languedoc. It comes as little surprise that the activities of friars as inquisitors engendered substantial antagonism among heterodox Christians. ${ }^{27}$ But violence occasionally erupted even when local communities were generally in favor of the inquisitors' presence, as attested by two distinct but interrelated cases in latethirteenth-century Italy.

In 1279, Parmese citizens responded to the burning of the maid of a convicted heretic by storming the local Dominican convent and killing one of the friars. ${ }^{28}$ What these men were

${ }^{27}$ Carol Lansing, Power and Purity: Cathar Heresy in Medieval Italy (New York: Oxford University Press, 1998); Mark Gregory Pegg, The Corruption of Angels: The Great Inquisition of 1245-1246 (Princeton: Princeton University Press, 2001).

28 Salimbene de Adam, Cronaca, ed. Giuseppe Scalia, Corpus Christianorum, Continuatio Mediaevalis CXXV-CXXV A (Turnholt: Brepols, 1998-1999), 733-37; Anonymous, Chronicon parmese ab anno 
disputing, apparently, was not the Inquisition's presence, but the verdict of guilt by association which befell the maid. The friars in this case were collectively punished for the abuses of a few, and when they left the city in protest many citizens were clearly satisfied. Indeed, the Parmese were willing to bear an interdict for nearly eight years before asking the friars to return. A decade later, a crowd gathered at Bologna to witness the burning of Giuliano and Bompietro, two convicted heretics, became outraged at the Dominican inquisitors' refusal to allow one of the condemned men to confess his sins and die a reconciled Christian. The uproar nearly turned into a mob-assault on the friars, but was eventually quelled. According to testimonies gathered in the immediate aftermath of the incident, members of the crowd openly expressed their desire to expel the Dominicans, "as was done in Parma." ${ }^{29}$ The same confessions disclose that the Bolognese had by then harbored many grudges against the local inquisitors, but it was only in denying a convicted heretic his last chance to return into the fold of orthodoxy that the friars sparked a dangerous insurrection.

Expelling friars from cities (or leaving them little choice but to depart) is attested elsewhere even outside the context of inquisitorial activities. One famous example comes from Strasbourg, and dates to the $1280 \mathrm{~s}$. There, the tensions revolved around the friars' access to urban property, rates of taxation, and methods of recruiting new members. The Franciscan convent eventually obeyed the commune's legislation on the matter, but the local Dominicans refused to cooperate. Soon the legal confrontation turned into a physical one, as some citizens blockaded the male convent, leaving the brothers with the choice of expulsion or starvation. Several ecclesiastical dignitaries,

mxxxvii usque ad annum mcccxxxviii, ed. Giuliano Bonazzi, Rerum Italicarum Scriptores IX pt. ix (Città di Castello: S. Lapi, 1902), 35-36.

${ }^{29}$ Bologna, Biblioteca dell'Archiginnasio, Ms. B. 1856 (antica 16*-gg1-1), fol. 42v. And see Eugenio Dupré-Theseider, "L'eresia a Bologna nei tempi di Dante," in Mondo cittadino e movimenti ereticali nel Medio Evo (saggi) (Bologna: Pàtron, 1978), 261-315, esp. 287-96; Augustine Thompson, Cities of God: The Religion of the Italian Communes, 11251325 (University Park, PA: The Pennsylvania State University Press, 2005), 433-56 
including the papal legate to the region, were understandably outraged, and an interdict closely followed. But many residents came to see the legate's response as an infringement of urban liberties by the Church. Friars were soon targeted throughout the region, and years of diplomacy would pass before the interdict was lifted and the friars could return to occupy their convent. ${ }^{30}$

Other instances disclose the occasionally prosaic nature of aggression aimed at friars. In 1362, fra Tommaso Aiutamichristo of Pisa, a Dominican subprior, precipitated a little stampede through the local convent after admitting a relative of his into the convent late at night for medical treatment. Tommaso was apparently misled. Upon opening the gate, a group of men, including the relative and another injured person, rushed into the compound seeking shelter from an angry mob. The latter soon appeared, broke into the convent, and conducted a violent search for the hiding group. ${ }^{31}$ In 1398, Ludovico Cittadini of San Miniato, then residing in Lucca, argued with fra Benedetto of Castro Fiorentino, an Augustinian Hermit, and then seized and beat him with a stone for an unmentioned reason. ${ }^{32}$ Other friars were victimized by robbers, both in and out of mendicant convents. ${ }^{33}$ In sum, friars were no strangers to violent hostility. ${ }^{34}$ Yet it is doubtful whether such cases merit being dubbed antifraternalism.

30 Sandrine Turck, Les dominicains à Strasbourg entre prêche, prière et mendicité 1224-1420 (Strasbourg: Société Savante d'Alsace, 2002), 3945 .

${ }^{31}$ Archivio Arcivescovile di Pisa, Atti Straordinari 8, fol. 80r-v (14 February 1362). Parallel cases are noted by Jens Röhrkasten, The Mendicant Houses of Medieval London, 1221-1539 (Münster: LIT Verlag, 2004), 190-92.

32 Archivio di Stato di Lucca, Sentenze e Bandi 94, fol. 15v (5 May 1398). For earlier cases see Archivio Diocesano di Lucca, Processi Criminali 17, fols. $102 \mathrm{r}-103 \mathrm{v}$ (11 August - 8 November 1361); 41, fol. 55r (29 May, 1391).

33 Archivio di Stato di Firenze, Capitano del Popolo 1002 bis, fol. 50r (31 January 1377); Jens Röhrkasten, Die englischen Kronzeugen, 1130 1330 (Berlin: Duncker \& Humblot, 1990), 348-49.

${ }^{34}$ Dupré-Thesieder, "L'eresia a Bologna nei tempi di Dante," 261. 315; and see my forthcoming Blotting the Elect: A Social History of Antifraternalism 
Indeed, it is difficult to tie violent assaults against friars to attitudes that would remain faithful to the ecclesiology of William of St. Amour. This is not to deny that some members of latemedieval society sought the orders' abolition, even if not on ecclesiological grounds. However, the available documentation suggests that the goals and motivations in these and other instances departed from William of St. Amour's ecclesiology. This, in turn, raises the question of whether such a literal definition of antifraternalism (or indeed the term itself) is useful for studying the range of negative attitudes toward religious mendicancy in the late Middle Ages. Sharp rhetoric and sharp blows may certainly attest contemporary dissatisfaction with the mendicants' discipline (or lack thereof), or bear witness to contemporary society's intolerance in general, but they provide little evidence of a common desire to see the friars eradicated. The radical quest for the friars' abolition, at least by a fervent few, would recommence in the early sixteenth century, nearly three-hundred years after the singular campaign led by William of St. Amour. 